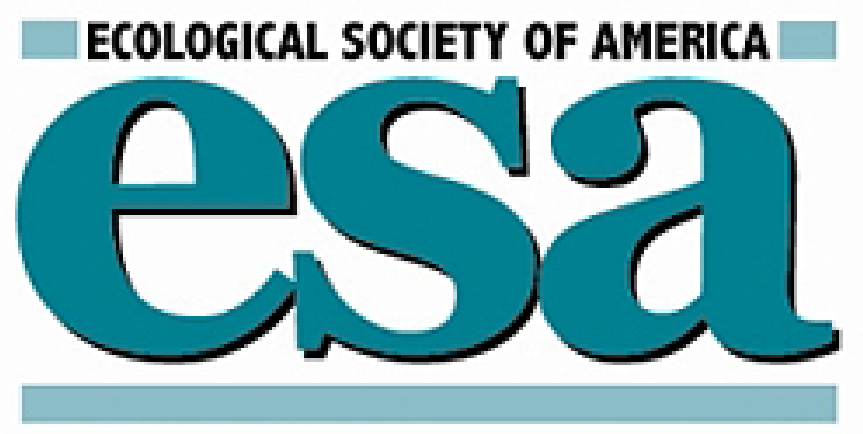

Phosphorus Spiralling in a Woodland Stream: Seasonal Variations

Author(s): Patrick J. Mulholland, J. Denis Newbold, Jerry W. Elwood, Leigh Ann Ferren and Jackson R. Webster

Source: Ecology, Vol. 66, No. 3 (Jun., 1985), pp. 1012-1023

Published by: Ecological Society of America

Stable URL: http://www.jstor.org/stable/1940562

Accessed: 13/03/2014 09:20

Your use of the JSTOR archive indicates your acceptance of the Terms \& Conditions of Use, available at http://www.jstor.org/page/info/about/policies/terms.jsp

JSTOR is a not-for-profit service that helps scholars, researchers, and students discover, use, and build upon a wide range of content in a trusted digital archive. We use information technology and tools to increase productivity and facilitate new forms of scholarship. For more information about JSTOR, please contact support@jstor.org. 


\title{
PHOSPHORUS SPIRALLING IN A WOODLAND STREAM: SEASONAL VARIATIONS ${ }^{1}$
}

\author{
Patrick J. Mulholland, J. Denis Newbold, ${ }^{2}$ Jerry W. Elwood, \\ ANd LeIGH ANN Ferren \\ Environmental Sciences Division, Oak Ridge National Laboratory, Oak Ridge, Tennessee 37831 USA
}

AND

JACKSON R. WEBSTER

Biology Department, Virginia Polytechnic Institute and State University, Blacksburg, Virginia 24061 USA

\begin{abstract}
Four radiotracer releases were performed over an annual period in 1981-1982 to determine seasonal variation in indices and pathways of phosphorus spiralling in Walker Branch, a small woodland stream in eastern Tennessee, USA. Each release consisted of an addition of $\approx 370 \mathrm{MBq}$ each of carrier-free ${ }^{32} \mathrm{PO}_{4}$ and ${ }^{3} \mathrm{H}_{2} \mathrm{O}$ over a 1 -h period during baseflow. Concentrations of ${ }^{32} \mathrm{P}$ and ${ }^{3} \mathrm{H}$ dissolved in stream water were measured intensively at several stations downstream from the radiotracer input during and immediately following each release. Activity of ${ }^{32} \mathrm{P}$ in coarse particulate organic matter (CPOM), fine particulate organic matter (FPOM), and aufwuchs was measured $2-3 \mathrm{~h}$ after each release and at various intervals for $7 \mathrm{wk}$. Total biomass of CPOM, FPOM, and aufwuchs at the time of each release was also measured.

Uptake of ${ }^{32} \mathrm{PO}_{4}$ from the water was greatest in November and lowest in August. Uptake length $\left(S_{w}\right)$ of phosphorus, defined as the average distance travelled by a $\mathrm{PO}_{4}$ ion dissolved in water, varied from $22 \mathrm{~m}$ in November to $97 \mathrm{~m}$ in August. Uptake of ${ }^{32} \mathrm{PO}_{4}$ by CPOM was generally greatest, with $\approx 50 \%$ of total uptake, while that by aufwuchs was lowest, with $<15 \%$ of the total. CPOM abundance was the major determinant of whole-stream $\mathrm{PO}_{4}$ uptake rate and $S_{w}$. Turnover length $\left(S_{p}\right)$ of phosphorus, defined as the average distance traveled by an atom of $\mathrm{P}$ taken up by particulate material, was short compared to $S_{w}$, varying from $1 \mathrm{~m}$ in November to $3 \mathrm{~m}$ in January. Consequently total spiralling length $(S)$ of $P$ varied from $23 \mathrm{~m}$ in November, just after peak autumn leaf fall, to $99 \mathrm{~m}$ in August, and reflected primarily the travel of $P$ in the dissolved form.

Our results indicate that the greatest increase in $S_{w}$ (and consequently in $S$ ) in Walker Branch occurs in late autumn or winter after storms reduce the abundance of CPOM in the lower portions of the stream bed. Although we calculate that $S_{p}$ may increase by one to two orders of magnitude for short periods during storms, the greatest effect of storms on P spiralling over the long term is their impact on the quality and quantity of CPOM and FPOM in the stream bed after the return to baseflow. For most of the year, detrital organic carbon probably influences phosphorus spiralling more than phosphorus spiralling influences the processing of organic carbon in Walker Branch. Only during the fall and early winter periods, when CPOM abundance is high and $S_{w}$ is short, does phosphorus spiralling exert strong control over biotic processes downstream.
\end{abstract}

Key words: phosphorus; radioisotope; recycling; spiralling length; stream ecosystem; Tennessee; transport.

\section{INTRODUCTION}

Webster (1975) and Webster and Patten (1979) suggested that nutrient cycles in streams be considered as spirals because of continuous downstream displacement of nutrients as they cycle. To describe the simultaneous processes of nutrient cycling and downstream transport in streams, Newbold, Elwood, and their coworkers further developed and quantified the concept of spiralling (Newbold et al. 1981, 1982, 1983, Elwood et al. 1983). Newbold et al. (1981) presented an index of spiralling, and reported results from a field measurement of phosphorus spiralling in July 1978 using radiotracers (Newbold et al. 1983). Stream eco-

\footnotetext{
${ }^{1}$ Manuscript received 19 December 1983; revised 29 May 1984; accepted 28 June 1984.

${ }^{2}$ Present address: Stroud Water Research Center, Avondale, Pennsylvania 19311 USA.
}

system models based on spiralling theory have also been developed (Newbold et al. 1982, 1983).

In this paper we present results on the seasonal variability of indices and pathways of phosphorus spiralling in Walker Branch, a small woodland stream in eastern Tennessee, USA. Changes in phosphorus spiralling in streams are expected as a result of seasonal variation in light, temperature, and organic matter storage. For streams with deciduous canopies, the organic matter budget is dominated by large inputs of leaves in autumn (e.g., Fisher and Likens 1973). Gregory (1978) has suggested that phosphorus uptake rates in streams should increase when standing crops of allochthonous organic matter are high. Large amounts of dissolved organic carbon (DOC) are leached and rapidly utilized by stream microbes during autumn (Lock and Hynes 1976, McDowell and Fisher 1976), perhaps increasing microbial phosphorus demand. Al- 
ternatively, autumn leaf inputs contribute substantially to the phosphorus supply of streams (Cowen and Lee 1973, Meyer and Likens 1979) and thus may reduce demand for phosphorus in the water. The pattern of microbial conditioning of decomposing leaves has also been shown to have a large influence on the dynamics of phosphorus (Gregory 1978, Meyer 1980) and nitrogen (Triska and Buckley 1978) in woodland streams. Using data from two previous ${ }^{32} \mathrm{PO}_{4}$ releases to Walker Branch, Elwood et al. (1983) estimated that the uptake length of $\mathrm{PO}_{4}$ (average distance traveled by a $\mathrm{PO}_{4}$ ion in water before uptake by stream microbes) was only $6 \mathrm{~m}$ immediately after peak autumn leaf fall, compared to $165 \mathrm{~m}$ in July. In this report we present results of a systematic investigation of seasonal changes in the patterns and controlling mechanisms of phosphorus spiralling in Walker Branch during 1981-1982.

\section{Study Site}

Our study was conducted in a $120-\mathrm{m}$ reach of the West Fork of Walker Branch, a first-order woodland stream located in the Ridge and Valley province of eastern Tennessee. Walker Branch flows from a 38.4ha experimental watershed on the Oak Ridge National Environmental Research Park. A detailed description of the system was given by Curlin and Nelson (1968). The stream is fed by springs and seeps that arise in dolomitic limestone. The stream gradient averages 55.9 $\mathrm{m} / \mathrm{km}$. Streamflow in the study reach is continuous, with low summer baseflows of 2-4 L/s and occasional brief winter and spring stormflows exceeding $50 \mathrm{~L} / \mathrm{s}$. Flow through the reach is augmented $10-25 \%$ by springs and groundwater seeps. During baseflow periods the stream averages $\approx 0.05 \mathrm{~m}$ in depth and $\approx 2.0 \mathrm{~m}$ in width.

Average concentrations of phosphorus and nitrogen, as soluble reactive phosphorus (SRP), $\mathrm{NO}_{3}-\mathrm{N}$, and $\mathrm{NH}_{4}$ $\mathrm{N}$, were 2,17 , and $72 \mu \mathrm{g} / \mathrm{L}$, respectively (from weekly data during 1972-1973, P. J. Mulholland et al., personal observation). Alkalinity averages $2.2 \mathrm{mmol} / \mathrm{L}$ and $\mathrm{pH} \approx 7.7$ (Elwood and Nelson 1972).

\section{MeTHODS}

We conducted a series of four tracer releases of ${ }^{32} \mathrm{PO}_{4}$ to the West Fork of Walker Branch over an annual period. Methods used in the study were similar to those used in a July 1978 experiment reported by Newbold et al. (1983).

About 1 wk prior to each tracer release, standing stocks of coarse particulate organic matter (CPOM, $>1$ $\mathrm{mm}$ ) and fine particulate organic matter (FPOM, $<1$ $\mathrm{mm}$ ) on the stream bottom were measured. We used stratified random sampling to locate 30 sample sites within relatively homogeneous habitats previously classified as gravel-riffle, bedrock-riffle, moss-riffle, or pool (see Newbold et al. 1983). Samples were taken by placing a stainless steel cylinder $\left(0.1 \mathrm{~m}^{2}\right.$ cross section) into (or on) the stream bottom as deeply as possible (generally $2-10 \mathrm{~cm}$ ). Water flow into the sampler was suppressed by tightly surrounding the cylinder with cloth towels. Large detritus was removed by hand and transferred to a sample container. Then the bottom material was vigorously agitated with a hand trowel and pumped with a Guzzler hand pump through a 263$\mu \mathrm{m}$ mesh net and into a large plastic container, until a volume of $40 \mathrm{~L}$ had been transferred. The substrate was sampled to the maximum depth that could be excavated with the trowel, usually $<10 \mathrm{~cm}$. The contents of the net were added to the sample of large detritus, which was returned to the laboratory, refrigerated within a few hours, and wet-sieved within a few days into $>1 \mathrm{~mm}$ (CPOM) and $<1 \mathrm{~mm}$ (FPOM) fractions. The contents of the large plastic container (FPOM $<263 \mu \mathrm{m}$ ) were thoroughly agitated and a $250-\mathrm{mL}$ subsample was taken, returned to the laboratory, and refrigerated. Within a few days the subsamples were filtered on pre-ashed glass-fiber filters (Whatman GF/ C) and processed for ash-free dry mass (AFDM) determination.

A solution containing $\approx 370 \mathrm{MBq}$ of ${ }^{32} \mathrm{P}$ as carrierfree $\mathrm{H}_{2}{ }^{32} \mathrm{PO}_{4}$ and $370 \mathrm{MBq}$ of tritium $\left({ }^{3} \mathrm{H}\right)$ as tritiated water was released to Walker Branch over a $1-\mathrm{h}$ period beginning between 1030 and 1200 on 18 November 1981 and on 18 January, 12 April, and 2 August 1982. Weather conditions during the releases ranged from overcast in January to partly cloudy on the other three dates. Tritium was added as a hydrologic tracer to correct for dilution and to determine the average water velocity. Water samples were collected from four or five stations along a $120-\mathrm{m}$ reach at 1 - or $2-\mathrm{min}$ intervals during and immediately following the release. At each station, CPOM, benthic and suspended FPOM, and aufwuchs were sampled 5-6 $\mathrm{h}$ after the release began (2-4 $\mathrm{h}$ after passage of the release slug) and for seven subsequent weeks at intervals increasing from 1 d to $1 \mathrm{wk}$.

During the release, water samples were collected in polyethylene syringes and filtered (Whatman GF/C) immediately. Then $5 \mathrm{~mL}$ of filtrate was added to 10 $\mathrm{mL}$ of scintillation cocktail (Aquasol) and counted for ${ }^{32} \mathrm{P}$ and ${ }^{3} \mathrm{H}$ on a Packard TRI-CARB $460 \mathrm{CD} /$ liquid scintillation spectrometer. Approximately 45 water samples were collected at each station as the ${ }^{32} \mathrm{P}$ and ${ }^{3} \mathrm{H}$ slug passed. CPOM samples consisted of leaves removed from the stream bottom and cut into small fragments. These were placed on tared planchets, dried at $80^{\circ} \mathrm{C}$, ashed at $450^{\circ}$ for determination of AFDM, and assayed for ${ }^{32} \mathrm{P}$ on a Harshaw TASC 12 planchet counter. The AFDM determination and ${ }^{32} \mathrm{P}$ assay were standard for all particulate samples. Benthic FPOM was sampled by aspirating sediments from depositional areas on the stream bottom. The sediments were collected on a glass-fiber filter (Whatman GF/C) and scraped from the filter onto tared planchets, and AFDM 
TABLE 1. Selected physical, chemical, and biological measurements of Walker Branch, Tennessee, on each of the indicated ${ }^{32} \mathrm{PO}_{4}$ release dates. Standard deviation and number of replicates given in parentheses.

\begin{tabular}{|c|c|c|c|c|}
\hline \multirow[b]{2}{*}{ Parameter } & \multicolumn{4}{|c|}{ Date of release } \\
\hline & 18 Nov 1981 & 18 Jan 1982 & 12 Apr 1982 & 2 Aug 1982 \\
\hline Streamflow at station $0(\mathrm{~L} / \mathrm{s})^{*}$ & 2.6 & 3.1 & 7.5 & 3.6 \\
\hline $\begin{array}{l}\text { Water temperature at station } 0 \text { and } 11 \\
\left({ }^{\circ} \mathrm{C}\right)^{*}\end{array}$ & 14,16 & 10,5 & 13,15 & 15,16 \\
\hline $\begin{array}{l}\text { Soluble reactive phosphorus (SRP) con- } \\
\text { centration }(\mu \mathrm{g} / \mathrm{L})\end{array}$ & $5(0.7,5)$ & $4(0.9,5)$ & $4(1.8,5)$ & $1(0.7,5)$ \\
\hline Seston concentration (AFDM, mg/L) & $0.50(0.03,4)$ & $0.64(0.03,4)$ & $0.77(0.05,4)$ & $0.69(0.05,4)$ \\
\hline \multicolumn{5}{|l|}{ Standing stocks (AFDM, $\mathrm{g} / \mathrm{m}^{2}$ ) } \\
\hline $\begin{array}{l}\text { Coarse particulate organic matter } \\
(\text { CPOM }) \dagger\end{array}$ & $536(340,30)$ & $102(110,30)$ & $185(240,30)$ & $75(90,30)$ \\
\hline $\begin{array}{l}\text { Fine particulate organic matter } \\
(\text { FPOM }) \dagger\end{array}$ & $340(350,30)$ & $210(200,30)$ & $400(305,30)$ & $370(380,30)$ \\
\hline FPOM $<263 \mu \mathrm{m}(\%$ of total $)$ & $82 \%$ & $79 \%$ & $73 \%$ & $78 \%$ \\
\hline Aufwuchs $\ddagger$ & $1.8(0.6,5)$ & $0.6(0.3,10)$ & $0.4(0.2,10)$ & $0.6(0.3,10)$ \\
\hline
\end{tabular}

* Station 0 is the upstream and station 11 the downstream boundary of the study reach.

$\dagger$ Measured $1 \mathrm{wk}$ prior to date of ${ }^{32} \mathrm{PO}_{4}$ release.

¥ January value was measured on 27 January 1982. April value was measured on 22 April 1982.

and ${ }^{32} \mathrm{P}$ activity were determined. Suspended FPOM (seston) was sampled by filtering $1 \mathrm{~L}$ of streamwater in the field through pre-ashed, tared glass-fiber filters (Whatman GF/C). Aufwuchs were scraped from rocks removed from the stream bed immediately after the release in November and January and washed onto tared planchets. The surface area from which the aufwuchs had been removed was traced on paper, cut, and computed by weighing the cuttings. During the April and August experiments, roughened Plexiglas slides $\left(34 \mathrm{~cm}^{2}\right)$ were placed at three stations $6-8 \mathrm{wk}$ prior to the release for aufwuchs colonization. Aufwuchs were sampled by scraping material from the slides onto tared planchets. A study conducted during April indicated that aufwuchs biomass on slides averaged only $\approx 40 \%$ of that scraped from a similar area of rock surface. Therefore, to compute biomass of aufwuchs during August, the data from slides was increased by a factor of 2.5 .

All ${ }^{32} \mathrm{P}$ assay values for each tracer release were corrected for decay (to one common time for each release), background activity, and counting efficiency. Results for particulate samples were recorded as either becquerels per milligram AFDM or becquerels per square metre of stream bottom, based on the standing stocks of each component (CPOM, FPOM, aufwuchs) in each habitat type and on the area of each habitat type in each reach.

To compute rates of stable phosphorus uptake from the radiotracer data, specific activity of ${ }^{32} \mathrm{PO}_{4}$ in stream water during each release was determined. Total available phosphorus was estimated as soluble phosphorus reacting with molybdate. Samples of stream water for determination of soluble reactive phosphorus (SRP) were collected at each station and immediately filtered through washed glass-fiber filters (Whatman GF/C) into acid-washed $25-\mathrm{mL}$ polyethylene bottles kept chilled, then frozen within $4 \mathrm{~h}$ of collection. SRP concentrations were determined using automated methods (Technicon 1974).

Studies of ${ }^{32} \mathrm{PO}_{4}$ equilibration in streamwater between dissolved (passing through a Whatman GF/C filter) and particulate (seston) forms were performed in the laboratory in conjunction with each release. Water from Walker Branch was collected just upstream of ${ }^{32} \mathrm{PO}_{4}$ input within a few days after the January, April, and August ${ }^{32} \mathrm{PO}_{4}$ releases, on 16 December 1981 (4 wk after the November release), and again on 15 November 1982. From each sample, 1-1.5 L of stream water was incubated in continuously stirred, darkenedglass reactors in triplicate at temperatures within $5^{\circ}$ of ambient stream water. Approximately $40 \mathrm{kBq}$ of carrier-free ${ }^{32} \mathrm{PO}_{4}$ was added to each reactor, and ${ }^{32} \mathrm{P}$ activity in dissolved and suspended particulate fractions was monitored for 2-5 d. Periodically during the incubation period, $20 \mathrm{~mL}$ of stream water were filtered (Whatman GF/C) and $5 \mathrm{~mL}$ of the filtrate was counted by liquid scintillation. Material retained on filters was rinsed with distilled water, dried, and ashed, and the ${ }^{32} \mathrm{P}$ was assayed on the planchet counter. After correcting for differences in counting efficiency, background, and decay for samples counted with different techniques, we computed the relative activity of ${ }^{32} \mathrm{P}$ associated with seston and dissolved in water over time in each reactor. Steady-state distribution of ${ }^{32} \mathrm{P}$ between water and seston was generally achieved within $2-4 \mathrm{~h}$ after ${ }^{32} \mathrm{PO}_{4}$ addition. Although sorption of ${ }^{32} \mathrm{PO}_{4}$ to walls of the glass reactors did occur, it did not effect our computation of ${ }^{32} \mathrm{P}$ distribution between water and seston, since these were measured directly.

Water samples for seston were collected in $250-\mathrm{mL}$ plastic bottles at 10-min intervals during a number of 


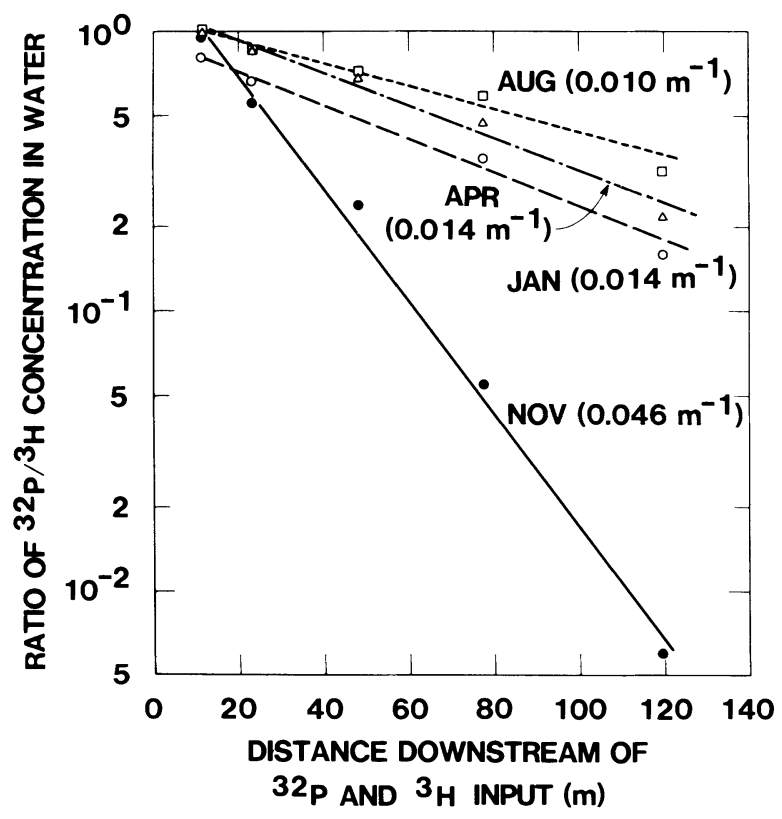

FIG. 1. Semi-logarithmic plot of means $(n=24-28)$ of ${ }^{32} \mathrm{P} /{ }^{3} \mathrm{H}$ concentration ratios during each release at various distances downstream from the input. (Standard errors are smaller than symbols $[\leq 3 \%$ of mean for all points] and thus are not shown in figure.) The inverse of the slope of each line (given in parentheses) is the uptake length of $\mathrm{PO}_{4}\left(S_{w}\right)$ during that release (Newbold et al. 1981).

storms by an automated fraction-collector activated when streamflow began to increase. The samples were retrieved within $2 \mathrm{~d}$, filtered on ashed, tared glass-fiber filters (Whatman GF/C), and processed for AFDM and ${ }^{32} \mathrm{P}$ activity. Streamflow at a station $\approx 25 \mathrm{~m}$ downstream was continuously measured and recorded during each storm as well as during baseflow periods.

\section{RESUlts}

\section{Environmental conditions}

Physical, chemical, and biological factors varied seasonally in Walker Branch (Table 1). Although all releases were performed during baseflow periods, streamflow at the upstream reach boundary (station 0 ) during the releases ranged from 2.6 to $7.5 \mathrm{~L} / \mathrm{s}$. Streamflow increased by nearly $20 \%$ over the $120 \mathrm{~m}$ experimental reach on 18 November 1981 and 18 January 1982, by $\approx 10 \%$ on 12 April 1982 , and by $3 \%$ on 2 August 1982 . Water temperature was lowest during the January release, decreasing from $10^{\circ}$ at station 0 to $5^{\circ}$ at the downstream boundary (station 11). During the other three releases, water temperature was higher and increased slightly from upstream to downstream. Water temperature at station 0 varied less than that at the other stations as a result of a large spring $\approx 20 \mathrm{~m}$ upstream that supplied about one-third of the total flow at a temperature ranging from $10^{\circ}$ to $13^{\circ}$ throughout the year.
Over the annual period beginning about the time of our first release in November, SRP concentration ranged from $<1 \mu \mathrm{g} / \mathrm{L}$ on a few occasions to $23 \mu \mathrm{g} / \mathrm{L}$ on one date in April, and averaged $2.9 \pm 2.0$ (SD), $3.4 \pm 3.1$, and $3.2 \pm 3.8 \mu \mathrm{g} / \mathrm{L}$ at the spring, station 0 , and station 11 , respectively ( $n=36$ samples for each station). There was no apparent seasonal trend, and the longitudinal variation in mean SRP concentration was not statistically significant $(P>.05)$.

Standing stock of CPOM was greatest during the November release, immediately after peak autumn leaf fall. On 4 January 1982 a large storm produced a peak streamflow of $114 \mathrm{~L} / \mathrm{s}$ (recurrence interval of 1-2 yr) and greatly reduced CPOM standing stock within the portion of the stream bed wetted during baseflow. Abundance of FPOM also declined from the November value. Minimum CPOM abundance occurred during August, while FPOM abundance increased from January to April and remained high in August. At all times, aufwuchs standing stock was low; however, it was about three times as great in November as in the other seasons. The relatively high November aufwuchs value may be the result of increased heterotrophic biomass supported by the large inputs of dissolved organic matter (DOM) leached from newly shed leaves. A number of researchers have shown that the autumn DOM influx to streams rapidly disappears from the water, via either uptake by heterotrophic microbes coating particulate surfaces (e.g., leaves, FPOM, clay, rocks) or physical adsorption to inorganic surfaces (Wetzel and Manny 1972, Lock and Hynes 1976, McDowell and Fisher 1976, Dahm 1981).

\section{Phosphorus uptake}

As the 1-h release slug passed downstream during each release, uptake of ${ }^{32} \mathrm{PO}_{4}$ conformed to an exponential decay model (Fig. 1); i.e., dissolved ${ }^{32} \mathrm{PO}_{4}$ concentration corrected for dilution decreased exponentially with distance downstream. The distance rate constants describing ${ }^{32} \mathrm{PO}_{4}$ uptake varied from 0.010 $\mathrm{m}^{-1}$ in August to $0.046 \mathrm{~m}^{-1}$ in November (Table 2). Time-specific and area-specific rate constants for total $\mathrm{PO}_{4}$ uptake were computed using SRP data, average water velocities, and the distance rate constants for ${ }^{32} \mathrm{PO}_{4}$ uptake (Table 2).

Of the three principal biotic stream bed components that take up $\mathrm{PO}_{4}$ directly from the water, aufwuchs had the highest mass-specific $\mathrm{PO}_{4}$ uptake rates and FPOM the lowest, for all releases (Table 2). The mass-specific $\mathrm{PO}_{4}$ uptake rate by aufwuchs was greatest during April, perhaps as a result of high light levels in early spring prior to development of the leaf canopy, while uptake rates by CPOM and FPOM were greatest in November, probably because of recent inputs of fresh leaves. The differences in uptake rates among aufwuchs, CPOM, and FPOM reflect the relative amount of active microbial biomass in each substrate. While much of the organic material scraped from rocks or glass slides may 
TABLE 2. Parameters describing uptake of $\mathrm{PO}_{4}$ on the basis of longitudinal distance, time, area of stream bed, and mass of stream substrates. Standard deviation given in parentheses when it could be calculated.

\begin{tabular}{|c|c|c|c|c|}
\hline & \multicolumn{4}{|c|}{ Date of release } \\
\hline & 18 Nov 1981 & 18 Jan 1982 & 12 Apr 1982 & 2 Aug 1982 \\
\hline Average water velocity $(\mathrm{cm} / \mathrm{s})$ & 2.3 & 3.0 & 5.5 & 4.0 \\
\hline $\begin{array}{l}\text { Distance rate constant for }{ }^{32} \mathrm{PO}_{4} \text { up- } \\
\text { take }\left(\mathrm{m}^{-1}\right)\end{array}$ & $0.0464(0.0021)$ & $0.0143(0.0011)$ & $0.0137(0.0012)$ & $0.0103(0.0010)$ \\
\hline $\begin{array}{l}\text { Time-specific uptake rate of } \mathrm{PO}_{4} \\
\left(\mathrm{~min}^{-1}\right)^{*}\end{array}$ & 0.062 & 0.027 & 0.046 & 0.026 \\
\hline $\begin{array}{l}\text { Area-specific } \mathrm{P} \text { uptake rate }\left(\text { as } \mathrm{PO}_{4}\right) \\
\left(\mu \mathrm{g} \mathrm{m}^{-2} \mathrm{~min}^{-1}\right) \dagger\end{array}$ & 15.5 & 5.4 & 11.1 & 1.3 \\
\hline \multicolumn{5}{|c|}{ Mass-specific $\mathrm{P}$ uptake rates $\left(\mathrm{ng} \mathrm{mg}^{-1} \mathrm{~h}^{-1}\right) \ddagger:$} \\
\hline $\begin{array}{l}\text { CPOM } \\
\text { FPOM } \\
\text { Aufwuchs }\end{array}$ & $\begin{array}{l}1.7(1.2) \\
1.2(0.5) \\
5.2(0.7)\end{array}$ & $\begin{array}{c}0.9(0.5) \\
0.3(0.2) \\
\cdots \S\end{array}$ & $\begin{array}{c}1.4(0.5) \\
0.3(0.1) \\
118(11)\end{array}$ & $\begin{array}{l}0.5(0.2) \\
0.1(0.02) \\
6.8(3.0)\end{array}$ \\
\hline \multicolumn{5}{|l|}{ Mass balance of ${ }^{32} \mathrm{P}$ uptake ( $\%$ of total) $\|:$} \\
\hline $\begin{array}{l}\text { CPOM } \\
\text { FPOM } \\
\text { Aufwuchs }\end{array}$ & $\begin{array}{r}89 \\
48 \\
5\end{array}$ & $\begin{array}{l}26 \\
23 \\
\ldots \S\end{array}$ & $\begin{array}{r}44 \\
23 \\
8\end{array}$ & $\begin{array}{r}48 \\
57 \\
9\end{array}$ \\
\hline Rapid release to water $\uparrow$ & 1 & 5 & 4 & 8 \\
\hline
\end{tabular}

* Fraction of available phosphorus pool in water taken up per unit time. Calculated by multiplying the distance rate constant of ${ }^{32} \mathrm{PO}_{4}$ uptake by the average water velocity.

† Calculated by multiplying the time-specific $\mathrm{P}$ uptake rate by the concentration of soluble reactive phosphorus [SRP] and the average water depth $(0.05 \mathrm{~m}$ in November, January, and August, $0.06 \mathrm{~m}$ in April).

$\ddagger$ Computed by multiplying specific activity of ${ }^{32} \mathrm{P}$ in substrates $\left({ }^{32} \mathrm{P} / \mathrm{mg}\right.$ AFDM) sampled $4 \mathrm{~h}$ after beginning of release at each station by specific activity of ${ }^{32} \mathrm{PO}_{4}$ in water $\left({ }^{32} \mathrm{PO}_{4} / \mathrm{SRP}\right)$ during passage of the release slug.

$\S$ Not measured.

$\|$ Computed by multiplying mass-specific ${ }^{32} \mathrm{P}$ uptake rates by average standing stocks and presented as $\%$ of total uptake as measured by disappearance of ${ }^{32} \mathrm{P}$ from water.

9 ${ }^{32} \mathrm{P}$ taken up by sediments but released back to water after passage of ${ }^{32} \mathrm{PO}_{4}$ slug but before initial sampling of sediments. Computed by comparing ratios of ${ }^{3} \mathrm{H}$ and ${ }^{32} \mathrm{P}$ concentrations in each water sample after passage of the ${ }^{32} \mathrm{PO}_{4}$ slug and ${ }^{3} \mathrm{H}$ and ${ }^{32} \mathrm{P}$ concentrations during passage of the ${ }^{32} \mathrm{PO}_{4}$ slug.

be living, CPOM and FPOM are composed primarily of nonliving organic material; a surface coating of living microbes makes up only a small fraction of the total mass. Despite a greater surface area per unit mass of FPOM, the lower mass-specific uptake rate of FPOM as compared with CPOM may indicate that microbes on FPOM are less active metabolically. Perhaps FPOM is of poorer quality as an organic substrate for microbial growth. Alternatively, a portion of FPOM sampled may not have been on the sediment surface and thus was more isolated from ${ }^{32} \mathrm{PO}_{4}$ in the overlying water than was CPOM.

A mass balance of ${ }^{32} \mathrm{P}$ taken up by stream substrates during each release was calculated (Table 2). Only for the April and August releases was the sum of ${ }^{32} \mathrm{PO}_{4}$ uptake accounted for by aufwuchs, CPOM, and FPOM (calculated using mass-specific uptake rates and standing stocks) within $25 \%$ of the total uptake computed from disappearance of ${ }^{32} \mathrm{PO}_{4}$ in the water over the experimental reach. In November, ${ }^{32} \mathrm{PO}_{4}$ uptake accounted for by CPOM, FPOM, and aufwuchs was considerably greater $(143 \%)$ than that computed as loss from the water. This may be the result of a sampling bias favoring surface CPOM and FPOM, which may have been more readily labeled than deeper substrates, particularly when standing stocks were large, as they were in November. The low fraction of total ${ }^{32} \mathrm{PO}_{4}$ uptake accounted for by CPOM and FPOM in January (54\% of total loss of ${ }^{32} \mathrm{PO}_{4}$ from water) is more puzzling. Certainly aufwuchs, which was not sampled after the release in January, was responsible for some of the uptake unaccounted for. Assuming a mass-specific ${ }^{32} \mathrm{PO}_{4}$ uptake rate by aufwuchs equal to that in April (when SRP concentrations were similar), aufwuchs would account for $12 \%$ of total ${ }^{32} \mathrm{PO}_{4}$ uptake in January. This leaves $\approx 35 \%$ of the total ${ }^{32} \mathrm{PO}_{4}$ loss from water still unaccounted for. Perhaps standing stocks of CPOM and/or FPOM were underestimated in January.

Despite the limited success of the mass balance of ${ }^{32} \mathrm{P}$, two observations can be made concerning partitioning of $\mathrm{PO}_{4}$ uptake in Walker Branch. First, although aufwuchs had high mass-specific $\mathrm{PO}_{4}$ uptake rates, the portion of whole-stream $\mathrm{PO}_{4}$ uptake by aufwuchs was relatively low (probably $<15 \%$ ) owing to very low biomass. Second, during most releases, CPOM was the most important stream substrate for removal of $\mathrm{PO}_{4}$ from water, although at times of relatively low CPOM abundance (e.g., January and August) $\mathrm{PO}_{4}$ uptake by FPOM was similar to that by CPOM.

\section{Phosphorus turnover}

Activity of ${ }^{32} \mathrm{P}$ in CPOM, FPOM, and aufwuchs over time followed multi-first-order kinetics, which indicates the existence of at least two phosphorus pools 
TABLE 3. Range of water temperature during the $7 \mathrm{wk}$ immediately following each ${ }^{32} \mathrm{P}$ release and turnover rates of ${ }^{32} \mathrm{P}$ associated with CPOM, FPOM, and aufwuchs (standard error and df in parentheses).

\begin{tabular}{|c|c|c|c|c|}
\hline & \multicolumn{4}{|c|}{ Date of release } \\
\hline & 18 Nov 1981 & 18 Jan 1982 & 12 Apr 1982 & 2 Aug 1982 \\
\hline Temperature range $\left({ }^{\circ} \mathrm{C}\right)$ & $10-16$ & $5-12$ & $11-16$ & $14-16$ \\
\hline \multicolumn{5}{|l|}{ Turnover rates $\left(\mathrm{d}^{-1}\right)^{*}$} \\
\hline $\begin{array}{c}\text { CPOM: rapid } \\
\text { slow }\end{array}$ & $\begin{array}{l}0.19(0.19,2) \\
0.09(0.03,5)\end{array}$ & $\begin{array}{l}0.61(0.10,3) \\
0.08(0.02,5)\end{array}$ & $\begin{array}{l}0.57(0.16,3) \\
0.02(0.01,5)\end{array}$ & $\begin{array}{l}0.69(0.05,3) \\
0.08(0.03,4)\end{array}$ \\
\hline $\begin{array}{c}\text { FPOM: rapid } \\
\text { slow }\end{array}$ & $\begin{array}{l}0.17(0.15,2) \\
0.04(0.01,5)\end{array}$ & $\begin{array}{l}0.26(0.19,2) \\
0.02(0.01,5)\end{array}$ & $\begin{array}{l}0.11(0.11,2) \\
0.03(0.01,5)\end{array}$ & $\begin{array}{l}0.13(0.05,2) \\
0.03(0.01,5)\end{array}$ \\
\hline $\begin{array}{c}\text { Aufwuchs: rapid } \\
\text { slow }\end{array}$ & $\begin{array}{l}\cdots+ \\
\cdots+\end{array}$ & $\begin{array}{l}\cdots+ \\
\cdots+\end{array}$ & $\begin{array}{l}0.32(0.09,3) \\
0.11(0.02,6)\end{array}$ & $\begin{array}{l}0.22(0.01,4) \\
0.03(0.01,3)\end{array}$ \\
\hline
\end{tabular}

* Turnover rates were calculated by fitting a two-compartment first-order model to data on ${ }^{32} \mathrm{P}$ content in each substrate over time at stations near the upper end of the experimental reach.

$\dagger$ Insufficient data to compute turnover rate.

associated with each substrate. Turnover of ${ }^{32} \mathrm{P}$ from the rapidly cycling pools dominated ${ }^{32} \mathrm{P}$ kinetics from $4 \mathrm{~h}$ after the ${ }^{32} \mathrm{P}$ release to $4-7 \mathrm{~d}$ later, and release from the slow pool dominated ${ }^{32} \mathrm{P}$ kinetics thereafter (to 49 d). Turnover rates of ${ }^{32} \mathrm{P}$ in both pools associated with CPOM were generally greatest, and turnover rates of ${ }^{32} \mathrm{P}$ in the slow FPOM and aufwuchs pools were generally lowest (Table 3 ). The lower ${ }^{32} \mathrm{P}$ turnover rates in FPOM as compared to CPOM are consistent with the lower mass-specific uptake rates by FPOM (Table 2 ). However, the relatively low ${ }^{32} \mathrm{P}$ turnover rates in aufwuchs are in contrast to the relatively high massspecific ${ }^{32} \mathrm{P}$ uptake rates by aufwuchs (Table 2), perhaps indicating relatively high net storage of phosphorus by aufwuchs compared to microbes associated with CPOM and FPOM. Further, the relatively low ${ }^{32} \mathrm{P}$ turnover rate in CPOM in November compared to other seasons (Table 3 ) is in contrast to the relatively high massspecific ${ }^{32} \mathrm{P}$ uptake rate by CPOM in November (Table 2 ), perhaps again indicating greater net storage of phosphorus by CPOM at this time.

\section{Indices of phosphorus spiralling}

The uptake length of $\mathrm{PO}_{4}$ in Walker Branch, designated $S_{w}$, was defined as the average distance travelled by a $\mathrm{PO}_{4}$ ion in water (Newbold et al. 1981, 1983) and was computed as the inverse of the distance rate constant for ${ }^{32} \mathrm{PO}_{4}$ uptake (Table 2). This distance was shortest in November $(22 \mathrm{~m})$ and longest in August $(97 \mathrm{~m})$ (Table 4). In earlier studies $S_{w}$ values of $6 \mathrm{~m}$ in November and $165 \mathrm{~m}$ in July were measured (Elwood et al. 1983). The present results concur with the pattern of a short $S_{w}$ in autumn after leaf fall and a long $S_{w}$ in summer; however, the range is not as great.

The importance of CPOM in $\mathrm{PO}_{4}$ uptake in Walker Branch is illustrated by the inverse relationship between $S_{w}$ and CPOM abundance (Fig. 2). When CPOM was abundant, as in autumn after leaf fall, uptake length of $\mathrm{PO}_{4}$ was shortest, which indicates that $\mathrm{PO}_{4}$ supplies were utilized most efficiently.

Phosphorus turnover length $\left(S_{p}\right)$, defined as the av- erage distance traveled by an atom of $\mathrm{P}$ taken up by particulate material, including microbes and algae (Newbold et al. 1981, 1983), can be computed from the total downstream flux of $P$ in dissolved and particulate phases. Newbold et al. (1981) showed that, for a stream at or near steady state, $S_{p}$ is related to the ratio of the particulate (seston) $\mathrm{P}$ flux $\left(F_{p}\right)$ and dissolved P flux $\left(F_{w}\right)$ by the following equation: $S_{p}=\left(F_{p} / F_{w}\right) S_{w}$. Although calculation of $F_{w}$ is straightforward, calculation of $F_{p}$ is complicated by the fact that not all of the seston $P$ is actively cycling and thus potentially exchangeable with the dissolved $P$ pool.

The ratio of exchangeable-P flux in seston $\left(F_{p}\right)$ to that dissolved in water $\left(F_{w}\right)$, was computed using data on the equilibrium distribution of ${ }^{32} \mathrm{P}$ between water and seston for stream water collected a few days after each release. The equilibration experiment following the 18 November 1981 release was not performed until 16 December 1981. An additional equilibration experiment was performed on 15 November 1982 to approximate conditions during the previous year more closely. Although steady-state distribution of ${ }^{32} \mathrm{P}$ between water and seston was usually achieved within the first 2-4 h and was usually maintained for 1-2 d, during the August 1982 experiment an initial steady state was achieved after only a few minutes but was maintained for only 2-4 h. Other investigators (Lean 1973, Berman and Skyring 1979, Tarapchak et al. 1981) have reported rapid ( $30 \mathrm{~min}$ to a few hours) biotic equilibration of ${ }^{32} \mathrm{P}$ between bacteria or algae and lake water. In our study, stream-water incubations carried out for $>24-48 \mathrm{~h}$ resulted in increases in particle concentration and a second phase of net ${ }^{32} \mathrm{P}$ uptake by particles in all experiments, probably the result of artifacts of incubating samples in containers (e.g., wall growth and subsequent sloughing). Therefore, the ${ }^{32} \mathrm{P}$ distribution during the steady state achieved in the first 2-4 h was used to compute $F_{p} / F_{w}$ for all experiments.

Steady-state distributions of ${ }^{32} \mathrm{P}$ on seston were $\leq 5 \%$ of the total ${ }^{32} \mathrm{P}$ dissolved in water at all times (Table 5). These distribution values are much lower than val- 
ues reported for lake seston (Lean 1973, Tarapchak et al. 1981), probably reflecting lower seston concentrations and/or lower microbial activity associated with stream seston compared with lake seston. Values of $S_{p}$, computed from the steady-state ${ }^{32} \mathrm{P}$ distribution between seston and water, were $\leq 3 \mathrm{~m}$ for all releases, much lower than the respective values of $S_{w}$ (Table 4). Thus, total spiralling length of phosphorus ( $S$, equal to $S_{w}+S_{p}$ ) was dominated by $S_{w}$, and its seasonal variation is due to variation in $S_{w}$ (Table 4 ).

\section{Storm effects}

The large storm of 4 January 1982 (peak flow of 114 $\mathrm{L} / \mathrm{s}$ ) greatly reduced CPOM abundance. Average standing stock of CPOM decreased by $434 \mathrm{~g} / \mathrm{m}^{2}$ over a period of $63 \mathrm{~d}$ : from $536 \mathrm{~g} / \mathrm{m}^{2}$ measured on 9 and 10 November 1981 to $102 \mathrm{~g} / \mathrm{m}^{2}$ measured on 12 January 1982, a decline of $81 \%$ (Table 1). Decomposition processes alone were calculated to account for only $\approx 60 \%$ of the decline in CPOM standing stock $\left(\approx 270 \mathrm{~g} / \mathrm{m}^{2}\right)$ during this period (Elwood et al. 1981a). We attribute the additional CPOM reduction of $164 \mathrm{~g} / \mathrm{m}^{2}(\approx 60 \%$ of the CPOM available just prior to the 4 January storm) to the scouring effects of the storm.

To determine the fate of the CPOM removed from the stream bed during this storm, on 12 January 1982 we attempted to compute a mass balance of ${ }^{32} \mathrm{P}$-labeled CPOM in portions of the stream channel and bank flooded during large storms. After correcting for radioisotope decay and ${ }^{32} \mathrm{P}$ release from CPOM since the November release, we could account for only $\approx 36 \%$ of the expected CPOM ${ }^{32} \mathrm{P}$ activity on the stream bed, and another $18 \%$ on stream banks. This leaves $\approx 46 \%$ of the expected CPOM ${ }^{32} \mathrm{P}$ activity unaccounted for; it was washed downstream. Although the movement of CPOM out of the reach by way of fluvial processes could have occurred any time after the November 1981 release of ${ }^{32} \mathrm{PO}_{4}$, the storm of 4 January 1982 was the first sizeable storm since the release. We observed, visually, little decline in CPOM standing stock in the study reach prior to that event. Thus, we estimate that the January storm was responsible for removing $\approx 64 \%$ of the CPOM standing stock from the stream bed of the experimental reach. However, $\approx 30 \%$ of the CPOM removed ( $18 \%$ of the CPOM standing stock) was not transported any great distance downstream, but was

TABLE 4. Uptake length $\left(S_{w}\right)$, turnover length $\left(S_{p}\right)$, and total spiralling length $(S)$ of phosphorus in the experimental reach of Walker Branch.

\begin{tabular}{cccc}
\hline \hline $\begin{array}{l}\text { Date of } \\
\text { release }\end{array}$ & $S_{w}(\mathrm{~m})$ & $S_{p}(\mathrm{~m})$ & $S(\mathrm{~m})$ \\
\hline 18 Nov 1981 & 22 & 1 & 23 \\
18 Jan 1982 & 70 & 3 & 73 \\
12 Apr 1982 & 73 & 2 & 75 \\
2 Aug 1982 & 97 & 2 & 99 \\
\hline
\end{tabular}

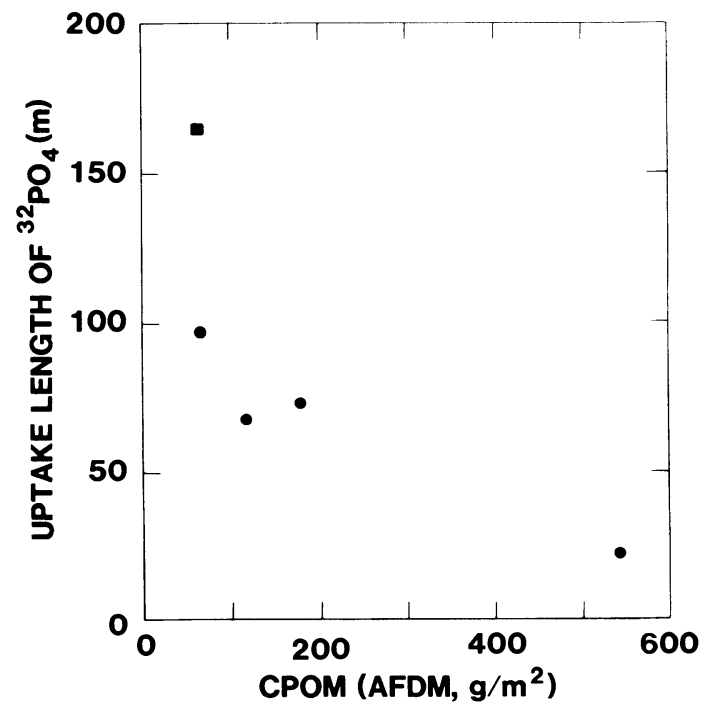

FIG. 2. Plot of uptake length of $\mathrm{PO}_{4}$ vs. coarse particulate organic matter (CPOM) standing stock on dates when both were measured. Data points presented are for the four ${ }^{32} \mathrm{PO}_{4}$ releases in 1981-1982 (๑) and for the ${ }^{32} \mathrm{PO}_{4}$ release in July $1978(\square)$.

deposited in unwetted regions of the stream channel (islands and debris accumulations above-water during baseflow) or on stream banks within the reach.

We also intensively sampled seston during a number of storms following ${ }^{32} \mathrm{PO}_{4}$ releases. Seston mass concentration increased rapidly at the onset of rainfall and peaked prior to the peak in streamflow, as has been observed in other studies (e.g., Bilby and Likens 1979, Webster 1983). Concentrations of ${ }^{32} \mathrm{P}$ in the seston (measured as becquerels per milligram AFDM) during storms were substantially lower than ${ }^{32} \mathrm{P}$ concentrations found in seston just prior to storms. Results from the largest storm sampled (peak streamflow of $82 \mathrm{~L} / \mathrm{s}$ ), which began on 20 January $1982 \approx 40 \mathrm{~h}$ after release of ${ }^{32} \mathrm{PO}_{4}$, illustrate the general trends in mass and ${ }^{32} \mathrm{P}$ concentration for seston found during storms (Fig. 3). During the 2-h period of peak seston mass concentration (580-700 min; Fig. 3), mean seston ${ }^{32} \mathrm{P}$ concentration was $1.4 \mathrm{~Bq} / \mathrm{mg}$ AFDM, one-sixth of the seston ${ }^{32} \mathrm{P}$ concentration prior to the storm, indicating dilution of ${ }^{32} \mathrm{P}$-labeled seston with unlabeled seston. However, this decline in seston ${ }^{32} \mathrm{P}$ content was not commensurate with the even larger increase in seston mass concentration, which increased by a factor of 24 , from a prestorm value of $0.6 \mathrm{mg} / \mathrm{L}$ to a mean of $14.3 \mathrm{mg} / \mathrm{L}$ during this 2 -h period. Thus, $\approx 75 \%$ of the increase in seston concentration during the rising limb of the storm hydrograph was generated from within the ${ }^{32} \mathrm{P}$-labeled study reach, i.e., within the $120 \mathrm{~m}$ of stream wetted during baseflow immediately upstream from our sampling location. This implies that during storms in Walker Branch, average travel distance of seston particles is 
TABLE 5. Results of studies of ${ }^{32} \mathrm{P}$ equilibration between seston and water in Walker Branch conducted in conjunction with ${ }^{32} \mathrm{PO}_{4}$ releases. Standard deviation and number of replicates in parentheses.

\begin{tabular}{cccl}
\hline \hline & $\begin{array}{c}\text { Seston } \\
\text { concen- } \\
\text { tration } \\
(\text { AFDM, } \\
\text { mg/L) }\end{array}$ & $\begin{array}{c}\text { Tempera- } \\
\text { ture } \dagger \\
\left({ }^{\circ} \mathrm{C}\right)\end{array}$ & \multicolumn{1}{c}{$\begin{array}{c}D^{*} \\
\left(F_{p} / F_{w}\right)\end{array}$} \\
\hline 12 Dec 1981 & 0.30 & 9 & $0.05(0.01,3)$ \\
20 Jan 1982 & 0.42 & 7 & $0.04(0.01,3)$ \\
19 Apr 1982 & 0.70 & 17 & $0.02(0.004,3)$ \\
3 Aug 1982 & 0.73 & 15 & $0.02(0.002,3) \ddagger$ \\
15 Nov 1982§ & 0.37 & 15 & $0.03(0.02,3)$ \\
\hline
\end{tabular}

* Steady-state ratio of ${ }^{32} \mathrm{P}$ in seston $\left(F_{p}\right)$ and ${ }^{32} \mathrm{P}$ in water $\left(F_{w}\right)$ is presented as the ${ }^{32} \mathrm{P}$ fraction associated with seston ( $D=F_{p} / F_{w}$; see Results: Indices of Phosphorus Spiralling).

$\dagger$ Incubation temperatures were chosen to approximate field conditions.

$\ddagger$ Seston ${ }^{32} \mathrm{P}$ distribution did not reach steady state during first $48 \mathrm{~h}$ (see Results: Indices of Phosphorus Spiralling).

$\S$ Additional study conducted because 16 December 1981 study was 4 wk after ${ }^{32} \mathrm{PO}_{4}$ release (18 November 1981 ).

probably $<120 \mathrm{~m}$ and perhaps not greatly longer than at baseflow.

For the storm that began on 20 January 1982, seston ${ }^{32} \mathrm{P}$ flux at station 11 during the 24 -h period of greatest transport was 13 times as great as seston ${ }^{32} \mathrm{P}$ flux during a 24-h baseflow period $1 \mathrm{~d}$ earlier. If, as assumed, the rate of $P$ remineralization from seston did not increase during the storm, then the average $S_{p}$ increased by more than an order of magnitude over that at baseflow during this period (Table 4).

\section{DisCUSSION}

Spiralling theory assumes a strong biological control of nutrient uptake and release in streams (Newbold et al. 1982, Elwood et al. 1983). Although Meyer (1979) reported that abiotic sorption by stream bed sediments controlled phosphorus concentrations in Bear Brook, New Hampshire, studies of other streams in Oregon (Gregory 1978) and Michigan (Ball and Hooper 1961), USA, and in New Zealand (Vincent and Downes 1980) indicated strong biotic control of phosphorus uptake. In hard-water streams such as Walker Branch, precipitation of calcium carbonate could remove $\mathrm{PO}_{4}$ from solution. Total alkalinity and dissolved $\mathrm{Ca}$ concentrations in Walker Branch exhibit a seasonal pattern, with summer and early autumn maxima of $2.8 \mathrm{mmol} / \mathrm{L}$ and $30 \mathrm{mg} / \mathrm{L}$, respectively, at $\mathrm{pH}$ of 8.1 (J. W. Elwood, personal observation). However, data on ${ }^{32} \mathrm{P}$ content of seston during our experimental releases indicated that uptake onto suspended particles was very low compared to total loss from the water, even during the summer and autumn studies. Total amount of ${ }^{32} \mathrm{P}$ retained on filters during passage of the ${ }^{32} \mathrm{PO}_{4}$ slug at each stream station during each release was $<1 \%$ of the ${ }^{32} \mathrm{P}$ loss from water between each set of stations, distances ranging from 10 to $43 \mathrm{~m}$. Even if the mean travel distance of precipitated $\mathrm{CaCO}_{3}$ particles was only a few metres prior to deposition on the stream bottom, co-precipitation of ${ }^{32} \mathrm{PO}_{4}$ would still be $<5 \%$ of the measured ${ }^{32} \mathrm{P}$ loss from water during each release. Past studies of phosphorus spiralling in Walker Branch have also indicated that $>90 \%$ of phosphorus uptake by sediments on the stream bottom is due to biotic processes (Elwood et al. 1981a).

It is also possible that we overestimated dissolved ${ }^{32} \mathrm{PO}_{4}$ concentrations at downstream stations in Walker Branch during some releases if ${ }^{32} \mathrm{PO}_{4}$ adsorbed to very small $(<1.2 \mu \mathrm{m}) \mathrm{CaCO}_{3}$ particles that passed through the GF/C filters used to separate dissolved from particulate fractions. This potential overestimation of biologically available ${ }^{32} \mathrm{PO}_{4}$ dissolved in water would result in similar overestimation of the biologically mediated $\mathrm{PO}_{4}$ uptake length $\left(S_{w}\right)$. To determine whether ${ }^{32} \mathrm{PO}_{4}$ adsorption to small particles occurs, water samples ( $1 \mathrm{~L}$ ) were collected at two stations in Walker Branch on 15 May 1984, spiked with ${ }^{32} \mathrm{PO}_{4}$, and incubated for $1 \mathrm{~h}$, and each of four replicate subsamples was filtered through $\mathrm{GF} / \mathrm{C}, 0.4 \mu \mathrm{m}$ Nuclepore, and 0.2 $\mu \mathrm{m}$ Nuclepore filters. Total alkalinity was $1.8 \mathrm{mmol} / \mathrm{L}$ and $\mathrm{pH}$ was 7.9 at this time. No differences between filter types in the concentrations of ${ }^{32} \mathrm{P}$ in the filtrate were observed which indicates that no measurable ${ }^{32} \mathrm{PO}_{4}$ adsorption to particles in the size range $0.2-1.2 \mu \mathrm{m}$ occurred. Although it is still possible that some adsorption may occur in summer and autumn when $\mathrm{Ca}$ concentrations and $\mathrm{pH}$ are at maximum values, the large decrease in $S_{w}$ between these two seasons was

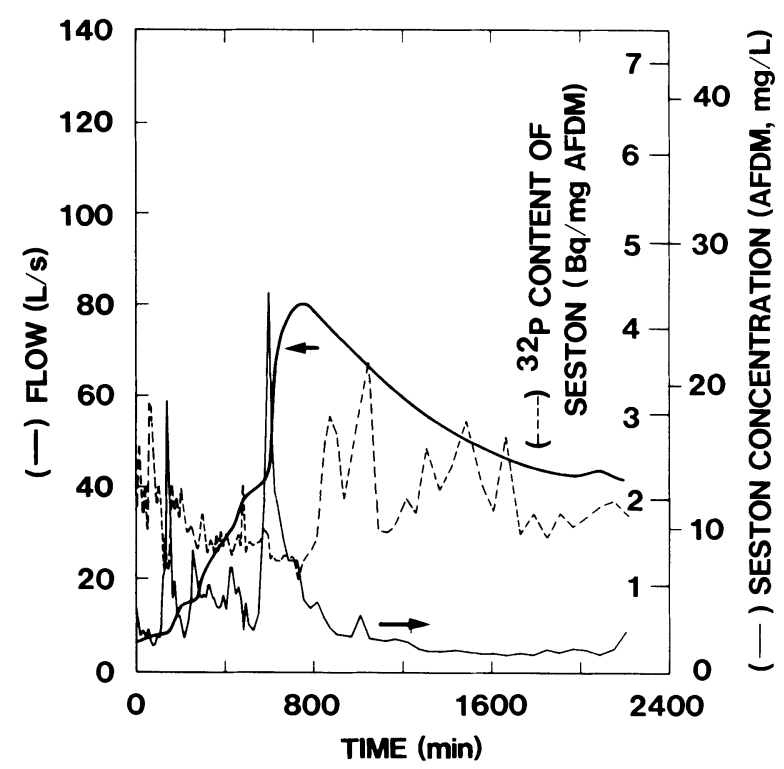

FIG. 3. Seston concentrations and ${ }^{32} \mathrm{P}$ concentrations in seston collected during a storm in Walker Branch beginning 20 January $1982, \approx 40 \mathrm{~h}$ after release of ${ }^{32} \mathrm{PO}_{4}$. Arrows on curves point to the associated ordinate scale. 
probably not the result of differences in ${ }^{32} \mathrm{PO}_{4}$ adsorption to fine $\mathrm{CaCO}_{3}$ particles.

Our data indicate an inverse relationship between $\mathrm{PO}_{4}$ uptake rate and standing stock of CPOM in Walker Branch (Fig. 2). Our data also indicate that water velocity may positively influence $\mathrm{PO}_{4}$ uptake rate. In April, when water velocity was greatest, time- and area-specific uptake rates were somewhat higher (Table 2) than might have been expected from CPOM abundance data alone (Table 1). Various researchers (Lock and John 1979, Horner and Welch 1981) have reported a stimulation of phosphorus uptake by periphyton with increasing water velocities. Although increases in water velocity may stimulate $\mathrm{PO}_{4}$ uptake rates by stream bed substrates, increases in water velocity also increase the rate of downstream transport of dissolved P. Our results from April indicate that the net result of these counteracting effects was to reduce the stream distance rate constant for $\mathrm{PO}_{4}$ uptake, consequently increasing $S_{w}$. We would have expected $S_{w}$ to be considerably shorter in April than in January because of higher CPOM abundance and greater area-specific $\mathrm{PO}_{4}$ uptake rates in April (Tables 1 and 2). However, $S_{w}$ was slightly longer in April than in January (Table 4) because increases in transport velocity compensated for increases in uptake of $\mathrm{PO}_{4}$. Our results emphasize the dependence of $S_{w}$ on factors controlling both uptake rates and transport rates of $\mathrm{PO}_{4}$, and indicate its usefulness as an index describing the simultaneous processes of $\mathrm{PO}_{4}$ utilization and downstream transport, which define stream ecosystem efficiency.

Our calculations of area-specific and mass-specific $\mathrm{PO}_{4}$ uptake rates were dependent upon the assumption that SRP represents total available phosphorus (i.e., that all forms are taken up as readily as $\mathrm{PO}_{4}$ ). Although there is considerable evidence indicating that the SRP measurement overestimates orthophosphate (Rigler 1968, Stainton 1980, Tarapchak et al. 1982), a recent study indicates that SRP is a reasonable estimate of biologically available phosphorus in most natural waters (Nurnberg and Peters 1984). If SRP measurements in Walker Branch overestimated total available phosphorus, our values for area-specific and mass-specific $\mathrm{PO}_{4}$ uptake were correspondingly overestimated (Table 2). However, our calculations of the distance rate constants for $\mathrm{PO}_{4}$ uptake and spiralling indices $\left(S_{w}\right.$ and $S_{p}$ ) were dependent only on ${ }^{32} \mathrm{P}$ dynamics during our tracer additions in the field and in the laboratory equilibration studies, and are not affected by uncertainties about the SRP measurement.

We should also note that our computations of $\mathrm{PO}_{4}$ uptake using tracer additions of ${ }^{32} \mathrm{PO}_{4}$ over a 1 -h period represent gross uptake rates. We presume that release of ${ }^{32} \mathrm{PO}_{4}$ taken up by stream substrates was minimal during the 1-h releases and that the depletion of ${ }^{32} \mathrm{P}$ dissolved in stream water as the slug passed stations at various distances downstream from the input represents gross ${ }^{32} \mathrm{PO}_{4}$ uptake. Actually, we observed slight

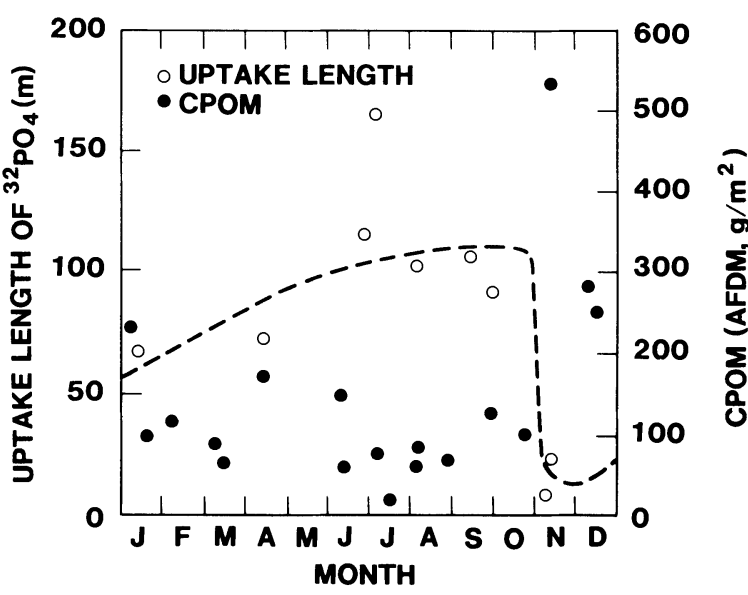

FIG. 4. Seasonal patterns of uptake length of $\mathrm{PO}_{4}$ and coarse particulate organic matter (CPOM) abundance in Walker Branch (data from 1968 to present).

increases in ${ }^{32} \mathrm{P}$ (relative to ${ }^{3} \mathrm{H}$ ) during the latter portion of the slug passage at the most downstream station, and these data were deleted when computing average ${ }^{32} \mathrm{P}$ concentrations at that station. Thus, $S_{w}$ calculated from the tracer data reflects the dynamic behavior of $\mathrm{PO}_{4}$ despite the apparent steady-state concentrations (SRP concentrations) with distance and time.

From data of past releases of ${ }^{32} \mathrm{PO}_{4}$ to Walker Branch as well as those of this study, a seasonal pattern in uptake length of $\mathrm{PO}_{4}$ emerges (Fig. 4). After autumn leaf fall, when CPOM standing stock in Walker Branch is at its maximum, $S_{w}$ is at its minimum. Usually a storm occurs in late fall or early winter that is large enough to reduce the standing stock of CPOM within portions of the stream bed inundated during baseflow. This reduction in CPOM results in a similar reduction in $\mathrm{PO}_{4}$ uptake from stream waters, and consequently an increase in $S_{w}$. During spring and summer, $S_{w}$ increases further in response to a gradual decline in CPOM standing stock. However, occasional new inputs of CPOM or reintroduction of stream-bank CPOM probably results in small decreases in $S_{w}$, particularly during spring. The $S_{w}$ measured during July $1978(165 \mathrm{~m})$ and reported in a previous paper (Newbold et al. 1983), is considerably longer than the other summer and early autumn values of $S_{w}$ (Fig. 4), and this may indicate that $S_{w}$ can exhibit considerable variability at this time of year. Although CPOM abundance $\left(85 \mathrm{~g} / \mathrm{m}^{2}\right)$, water velocity $(3.7 \mathrm{~cm} / \mathrm{s})$ and water temperature $\left(15^{\circ}-16^{\circ}\right)$ in July 1978 were similar to values measured in August 1982 when $S_{w}$ was only $97 \mathrm{~m}$ (Tables 1 and 4), FPOM abundance was considerably lower $\left(150 \mathrm{~g} / \mathrm{m}^{2}\right)$ in July 1978 (Newbold et al. 1983). Relatively low uptake of $\mathrm{PO}_{4}$ by FPOM in July 1978 may at least partially account for the longer $S_{w}$ at that time compared to August 1982.

While our data implicate the quantity of CPOM as 
a major determinant of the efficiency of $\mathrm{PO}_{4}$ utilization in Walker Branch, they do not reveal the importance of CPOM quality. In a separate study examining the role of microbial conditioning of CPOM on $\mathrm{PO}_{4}$ uptake in laboratory streams, we found the $\mathrm{PO}_{4}$ uptake by CPOM increased sharply, then declined during the first few weeks after leaves were added to the stream (Mulholland et al. 1984). However, the rate of $\mathrm{PO}_{4}$ uptake by CPOM and $S_{w}$ appeared to stabilize after CPOM had been in the streams $\approx 4-5$ wk. Therefore, during the first month after autumn leaf fall, $S_{w}$ may undergo an additional temporal pattern of shortening and lengthening due to changes in CPOM quality alone.

Although the spiralling of phosphorus is clearly essential to the function of the stream ecosystem, its immediate influence on other aspects of ecosystem dynamics depends on (1) the degree to which concentrations of available phosphorus are controlled within the stream ecosystem, and (2) the level of response of other ecosystem processes to variations in available phosphorus concentrations. In a theoretical analysis of the spiralling concept, Newbold et al. (1982) argued that these two conditions should vary together, i.e., that the ecosystem's influence on concentrations of dissolved, biologically available phosphorus increases as the degree of nutrient limitation increases. When both are high, spiralling mechanisms such as uptake, regeneration, and downstream transport of nutrients should strongly influence other ecosystem dynamics (such as primary production, microbial decomposition, secondary production), and such influences can be transmitted downstream. Newbold et al. (1982) predicted that strong nutrient limitation in Walker Branch should be reflected in relatively low $S_{w} / S_{p}$ ratios (values approaching unity).

The lack of significant differences between SRP concentrations in spring water and in stream water downstream throughout the year in Walker Branch would appear to indicate a lack of ecosystem control of available phosphorus concentrations and hence a lack of strong phosphorus limitation. However, depletion of up to $1-2 \mu \mathrm{g} / \mathrm{L}$ in SRP concentration might not have been evident from our data due to a lack of sensitivity of our method of measurement. Measurements of SRP repeated on the same samples using our automated technique (Technicon 1974) indicated an average deviation of $2 \mu \mathrm{g} / \mathrm{L}$ from the initial measurement. More recent measurements of SRP in Walker Branch using a more sensitive and precise nonautomated technique (Murphy and Riley 1962) indicated a consistent depletion of SRP of $1-2 \mu \mathrm{g} / \mathrm{L}$ between spring water and stream water. The relatively large $S_{w} / S_{p}$ ratios measured in Walker Branch (22-48; Table 4) also appear to indicate a lack of strong phosphorus limitation. Nonetheless, Elwood et al. (1981b) reported a phosphorus limitation of leaf decomposition during winter and spring in Walker Branch, although conditions of their study may have more nearly represented those of autumn, because leaf packs of autumn-shed leaves were placed in the stream at the beginning of the study. Results of our present study indicating relatively low ${ }^{32} \mathrm{P}$ turnover rates in CPOM in November (Table 3) despite relatively high mass-specific ${ }^{32} \mathrm{P}$ uptake rates in November (Table 2) may also indicate relatively greater net phosphorus uptake by CPOM at that time. Therefore, our results in total indicate that phosphorus is most likely to be limiting in Walker Branch in late autumn and winter, when CPOM is maximum and $S_{w}$ is minimum. At this time of year, biota in downstream reaches of Walker Branch are most strongly influenced by phosphorus spiralling mechanisms in upstream reaches. By contrast, in summer, when CPOM is minimum and consequently phosphorus demand is lowest, $S_{w}$ is maximum and phosphorus spiralling has its least impact on ecosystem dynamics.

During storms, the flux of particulate phosphorus and $S_{p}$ in Walker Branch increases sharply, potentially removing phosphorus accumulated on the stream bed during interstorm periods. Malfunctions in our automated sampler prevented the determination of a complete budget on particulate transport during storms. However, it is possible to obtain an estimate for average annual storm transport. Huff et al. (1977) found that storms accounted for $17 \%$ of the flow in Walker Branch between 1971 and 1975. The flow-weighted annual average concentration of transported FPOM during all storms in $1974-1975$ was $8 \mathrm{mg} / \mathrm{L}$, or $\approx 15$ times the baseflow concentration (Comiskey 1978). Although we calculate that average CPOM concentration could be on the order of $10-20 \mathrm{mg} / \mathrm{L}$ during the first large storm following autumn leaf fall, over the entire year CPOM transport is small compared to FPOM transport (Sedell et al. 1978, Gurtz et al. 1980, Webster 1984). Thus, in an average year in which $17 \%$ of the flow is due to storms, $\approx 75 \%$ of the particulate organic matter transport may occur during storms. As we have shown in this study, most but not all of the extra particulate transport is derived from the stream bottom. Therefore, ignoring the extra dissolved transport that occurs during storms, the average annual proportion of the downstream flux of phosphorus that is in exchangeable particulate form is probably no more than $8-20 \%$, or four times that measured in baseflow.

In conclusion, this study further demonstrates the usefulness of the spiralling concept in analyzing nutrient dynamics in stream ecosystems. Seasonal variation in phosphorus spiralling length in Walker Branch is substantial and indicates a seasonal pattern in the efficiency with which supplies of $\mathrm{PO}_{4}$ are utilized, despite lack of temporal and longitudinal variation in such measures of phosphorus concentration as SRP. Additional studies are needed to determine if the observed annual patterns in phosphorus spiralling indices continue in Walker Branch and whether they exist in other streams with different physical and biological characteristics. Additional field measurements are also 
needed to determine how phosphorus spiralling indices vary between streams of similar size and longitudinally within stream systems.

Our study of annual variation in phosphorus spiralling has also shown that for most of the year, detrital organic matter influences phosphorus spiralling in Walker Branch probably more than phosphorus spiralling influences the processing of organic matter. Uptake of phosphorus and, by inference, ecosystem microbial production during much of the year appear to be limited by the abundance of CPOM and perhaps also by its quality (i.e., by availability of the biologically more labile carbon substances). Phosphorus spiralling is most likely to be important to metabolic processes in Walker Branch during late autumn and early winter, when CPOM abundance is large. Because of the relative unimportance of particulate transport in Walker Branch at baseflow, downstream influences of phosphorus spiralling, if they exist, are probably mediated temporally through storage and release (buffering), or possibly through downstream transport of dissolved organic phosphorus.

\section{ACKNOWLEDGMENTS}

We thank Paul T. Singley, Richard E. Perkins, Webster Van Winkle, and Ernest F. Benfield for their assistance with fieldwork and N. Marion Ferguson for chemical analyses of phosphorus concentrations. We also thank Ralph Turner, Bruce Kimmel, Webster Van Winkle, Carl Gehrs, Robert Naiman, Judy Meyer, and an anonymous reviewer for their reviews of the manuscript. This research was supported by the National Science Foundation's Ecosystem Studies Program under Interagency Agreement Number BSR 8103181, A02 with the United States Department of Energy, under Contract Number DE-AC05-840R21400 with Martin Marietta Energy Systems, Incorporated. This paper is Publication Number 2338, Environmental Sciences Division, Oak Ridge National Laboratory.

\section{Literature Cited}

Ball, R. C., and F. F. Hooper. 1961. Translocation of phosphorus in a trout stream ecosystem. Pages $217-228$ in $\mathrm{V}$. Schultz and A. W. Klement, Jr., editors. Radioecology. Reinhold, New York, New York, USA.

Berman, T., and G. W. Skyring. 1979. Phosphorus cycling in aquatic microorganisms studied by phased uptake of ${ }^{33} \mathrm{P}$ and ${ }^{32} \mathrm{P}$. Current Microbiology 2:47-49.

Bilby, R. E., and G. E. Likens. 1979. Effect of hydrologic fluctuations on the transport of fine particulate organic carbon in a small stream. Limnology and Oceanography 24: 69-75.

Chamberlain, W., and J. Shapiro. 1969. On the biological significance of phosphate analysis; comparison of standard and new methods with a bioassay. Limnology and Oceanography 14:921-927.

Comiskey, C. E. 1978. Aspects of the organic carbon cycle on Walker Branch Watershed: a study of land/water interaction. Dissertation. University of Tennessee, Knoxville, Tennessee, USA.

Cowen, W. F., and G. F. Lee. 1973. Leaves as a source of phosphorus. Environmental Science and Technology 7:853854.

Curlin, J. W., and D. J. Nelson. 1968. Walker Branch Watershed: objectives, facilities, and ecological characteristics. ORNL/TM-2271, Oak Ridge National Laboratory, Oak Ridge, Tennessee, USA.
Dahm, C. N. 1981. Pathways and mechanics for removal of dissolved organic carbon from leaf leachate in streams. Canadian Journal of Fisheries and Aquatic Sciences 38:6876.

Elwood, J. W., and D. J. Nelson. 1972. Periphyton production and grazing rates in a stream measured with a ${ }^{32} \mathrm{P}$ material balance method. Oikos 23:295-303.

Elwood, J. W., J. D. Newbold, R. V. O'Neill, R. W. Stark, and P. T. Singley. $1981 \mathrm{a}$. The role of microbes associated with organic and inorganic substrates in phosphorus spiralling in a woodland stream. Internationale Vereinigung für theoretische und angewandte Limnologie Verhandlungen 21:850-856.

Elwood, J. W., J. D. Newbold, R. V. O'Neill, and W. Van Winkle. 1983. Resource spiralling: an operational paradigm for analyzing lotic ecosystems. Pages 3-27 in T. D. Fontaine, III and S. M. Bartell, editors. Dynamics of lotic ecosystems. Ann Arbor Science, Ann Arbor, Michigan, USA.

Elwood, J. W., J. D. Newbold, A. F. Trimble, and R. W. Stark. $1981 \mathrm{~b}$. The limiting role of phosphorus in a woodland stream ecosystem: effects of $P$ enrichment on leaf decomposition and primary producers. Ecology 62:146-158.

Fisher, S. G., and G. E. Likens. 1973. Energy flow in Bear Brook, New Hampshire: an integrative approach to stream ecosystem metabolism. Ecological Monographs 43:421-439.

Gregory, S. V. 1978. Phosphorus dynamics on organic and inorganic substrates in steams. Internationale Vereinigung für theoretische und angewandte Limnologie Verhandlungen 20:1340-1346.

Gurtz, M. E., J. R. Webster, and J. B. Wallace. 1980. Seston dynamics in southern Appalachian streams: effects of clearcutting. Canadian Journal of Fisheries and Aquatic Sciences 37:624-631.

Horner, R. R., and E. B. Welch. 1981. Stream periphyton development in relation to current velocity and nutrients. Canadian Journal of Fisheries and Aquatic Sciences 38: 449-457.

Huff, D. D., G. S. Henderson, C. L. Begovich, R. J. Luxmoore, and J. R. Jones. 1977. The application of analytic and mechanistic hydrologic models to the study of Walker Branch Watershed. Pages 741-763 in D. L. Correll, editor. Watershed research in eastern North America: a workshop to compare results. I. Chesapeake Bay Center for Environmental Studies, Smithsonian Institution, Edgewater, Maryland, USA.

Lean, D. R. S. 1973. Movements of phosphorus between its biologically important forms in lake water. Journal of the Fisheries Research Board of Canada 30:1525-1536.

Lock, M. A., and H. B. N. Hynes. 1976. The fate of dissolved organic carbon derived from autumn-shed maple leaves (Acer saccharum) in a temperate hard-water stream. Limnology and Oceanography 21:436-443.

Lock, M. A., and P. H. John. 1979. The effect of flow patterns on uptake of phosphorus by river periphyton. Limnology and Oceanography 24:376-383.

McDowell, W. H., and S. G. Fisher. 1976. Autumnal processing of dissolved organic matter in a small woodland stream ecosystem. Ecology 57:561-569.

Meyer, J. L. 1979. The role of sediments and bryophytes in phosphorus dynamics in a headwater stream ecosystem. Limnology and Oceanography 24:365-375.

- 1980. Dynamics of phosphorus and organic matter during leaf decomposition in a forest stream. Oikos 34:4453.

Meyer, J. L., and G. E. Likens. 1979. Transport and transformation of phosphorus in a stream ecosystem. Ecology 60:1255-1269.

Mulholland, P. J., J. W. Elwood, J. D. Newbold, J. R. Webster, L. A. Ferren, and R. E. Perkins. 1984. Phosphorus uptake by decomposing leaf detritus: effect of microbial biomass 
and activity. Internationale Vereinigung für theoretische und angewandte Limnologie Verhandlungen 22:1899-1905.

Murphy, J., and J. P. Riley. 1962. A modified single solution method for the determination of phosphate in natural waters. Analytica Chimica Acta 27:31-36.

Newbold, J. D., J. W. Elwood, R. V. O'Neill, and A. L. Sheldon. 1983. Phosphorus dynamics in a woodland stream ecosystem: a study of nutrient spiralling. Ecology 64:12491265.

Newbold, J. D., J. W. Elwood, R. V. O'Neill, and W. Van Winkle. 1981. Measuring nutrient spiralling in streams. Canadian Journal of Fisheries and Aquatic Sciences 38: 860-863.

Newbold, J. D., R. V. O'Neill, J. W. Elwood, and W. Van Winkle. 1982. Nutrient spiralling in streams: implications for nutrient limitation and invertebrate activity. American Naturalist 120:628-652.

Nürnberg, G., and R. H. Peters. 1984. Biological availability of soluble reactive phosphorus in anoxic and oxic freshwaters. Canadian Journal of Fisheries and Aquatic Sciences 41:757-765.

Rigler, F. H. 1968. Further observations inconsistent with the hypothesis that the molybdenum blue method measures orthophosphate in lake water. Limnology and Oceanography 13:7-13.

1979. The export of phosphorus from Dartmoor catchments: a model to explain variations of phosphorus concentrations in streamwater. Journal of the Marine Biological Association of the United Kingdom 59:659-687.

Sedell, J. R., R. J. Naiman, K. W. Cummins, G. W. Minshall, and R. L. Vannste. 1978. Transport of particulate organic material in streams as a function of physical processes. Internationale Vereinigung für theoretische und angewandte Limnologie Verhandlungen 20:1366-1375.

Stainton, M. P. 1980. Errors in molybdenum blue methods for determining orthophosphate in freshwater. Canadian Journal of Fisheries and Aquatic Sciences 37:472-478.
Tarapchak, S. J., S. M. Bigelow, and C. Rubitschun. 1982. Overestimation of orthophosphorus concentrations in surface waters of southern Lake Michigan: effects of acid and ammonium molybdate. Canadian Journal of Fisheries and Aquatic Sciences 39:296-304.

Tarapchak, S. J., D. R. Slavens, and L. M. Maloney. 1981. Abiotic versus biotic uptake of radiophosphorus in lakewater. Canadian Journal of Fisheries and Aquatic Sciences 38:889-895.

Technicon. 1974. Technicon Auto Analyzer II. Technicon Industrial Systems, Tarrytown, New York, USA.

Triska, F. J., and B. M. Buckley. 1978. Patterns of nitrogen uptake and loss in relation to litter disappearance and associated invertebrate biomass in six streams of the Pacific Northwest, USA. Internationale Vereinigung für theoretische und angewandte Limnologie Verhandlungen 20:1324 1332.

Vincent, W. F., and M. T. Downs. 1980. Variation in nutrient removal from a stream by watercress (Nasturtium officinale $\mathrm{R}$. Br.). Aquatic Botany 9:221-235.

Webster, J. R. 1975. Analysis of potassium and calcium dynamics in stream ecosystems on three southern Appalachian watersheds of contrasting vegetation. Dissertation. University of Georgia, Athens, Georgia, USA.

-1983. The role of benthic macroinvertebrates in detritus dynamics of streams: a computer simulation. Ecological Monographs 53:383-404.

Webster, J. R., and B. C. Patten. 1979. Effects of watershed perturbation on stream potassium and calcium dynamics. Ecological Monographs 19:51-72.

Wetzel, R. G., and B. A. Manny. 1972. Decomposition of dissolved organic carbon and nitrogen compounds from leaves in an experimental hard-water stream. Limnology and Oceanography 17:929-931. 